\title{
Species identification and prevalence of gastrointestinal helminths in Indonesian native chickens, and its impact on egg production
}

\author{
LILI ZALIZAR, ARIS WINAYA", ABDUL MALIK, WAHYU WIDODO, SUYATNO, \\ APRILIANA DEVI ANGGRAINI \\ Department of Animal Science, Faculty of Agriculture and Animal Science, Universitas Muhammadiyah Malang. Jl. Raya Tlogomas 246 Malang 65144, \\ East Java, Indonesia. ”email: winaya@umm.ac.id
}

Manuscript received: 14 May 2021. Revision accepted: 24 September 2021.

\begin{abstract}
Zalizar L, Winaya A, Malik A, Widodo W, Suyatno, Anggraini AD. 2021. Species identification and prevalence of gastrointestinal helminths in Indonesian native chickens, and its impact on egg production. Biodiversitas 22: 4363-4369. Gastrointestinal parasite (GIP) infection is a severe problem of local chicken production, such as poultry and egg. Hence, the proper strategy to control the parasite invasion should be implemented regarding chicken productivity performance. Moreover, the existing environment is also essential in supporting chicken production. The study's objective was to determine the prevalence rate of the gastrointestinal helminths in four strains of Indonesian native chicken viz. Ranupane, Lokal Putih, Wareng, and Lurik, and the impact of the chicken egg production. A total of 280 chickens which were evaluated consisting of 70 birds from each strain, were tested for the prevalence of helminths eggs in a sample of feces and the effect on hen day production (HDP). The results showed that the percentage rates of infected chicken with helminths reached 56.43\%, and the number of eggs per gram (EPG) in all four strains was considered moderate (115 EPG of feces). At the same time, the average of HDP per the four strains at 7 to 12 months was about 34.36-45.80\%, which was in a normal range. The majority of helminths species found in examined native chicken were Ascaridia galli, Heterakis gallinarum, Raillietina spp., and Capillaria spp. The prevalence of GIP helminths did not negatively affect egg production in all four strains of chicken by moderately tolerant infections, and the HDP of chickens was normal.
\end{abstract}

Keywords: Ascaridia galli, Ayam Kampung, gastrointestinal, germplasm, hen day production

\section{INTRODUCTION}

Native chickens, known as Ayam Kampung, are the chicken breeding commonly rearing by people traditionally under free-range or backyard control. Native chickens are generally raised as a family business on a small- scale using family labor and, if possible, using a local feed source. Native chickens commonly roam around household living and scavenging much leftover or get additional feeds from the owner (Asmelash et al. 2018; Di Pillo et al. 2019). Besides, native chicken always fetches a better price than commercial chicken due to the taste and flavor (Mengesha 2012; Kumar et al. 2019). Therefore, these chicken breeds or strains must be preserved regarding their existence as native bio-resources. Some Indonesian native chicken strains, like Ranupane, Lokal Putih, Wareng, and Lurik, also can be found in the East Java region, Western Indonesia. The total population of Indonesian indigenous chickens in 2020 was 308,476,957 heads, and East Java province was the second-largest population by $40,372,808$ heads (BPS 2021). Hence, the native chicken in East Java province is interesting to study its characteristic performance, including the interrelationship complexity with environmental factors.

Meat production is estimated to increase by an average of $1.6 \%$ per year, and $50 \%$ of this increase in meat is estimated from poultry; thus, poultry production will increase by $1.9 \%$ per year. Furthermore, in 2022 poultry is projected to account for $37 \%$ of the global meat supply and become the largest meat sector in the world (OECD 2013). The productivity performance of chickens can be influenced by factors such as ambient temperature, feed, flock density, and water provision (Tarkhan et al. 2020). A study using Iodosteryl in water drink induced erythrocyte fragility at domestic chicken (Azzez et al. 2012). Water supply is an essential factor that will impact poultry industry productivity (Krauß et al. 2015). However, the development of chickens is greatly influenced by parasites. Poultry parasitic diseases cause difficulties in managing and developing chickens to optimal productivity (Van et al. 2020).

Parasites can be a significant factor limiting the productivity of chickens by affecting the growth rate of chickens and causes organ damage and eventually death (Negbenebor and Ali 2018). Hence, the immune response to helminth infection is complex and depends on various factors, including the location of the parasite in the host's body (invasive intestinal tissue), the specific helminths species, and the stage of the life cycle. However, the main response to helminths infections was marked with the emergence of eosinophilia, elevated serum immunoglobulins (Ig) E and $\mathrm{IgG} 4$, and mast cell hyperplasia (Siracusa and Gause 2016).

Helminth infections were widely observed in chickens, both extensively and semi-intensively rearing conditions. Therefore, the effective control measures of helminths 
infection can be realistic if based on comprehensive knowledge of the epidemiology of the endemic infectious agent. In poultry production, nematode parasites, cestodes, and trematodes were important parasites (Bachaya et al. 2015). Gastrointestinal parasitic infections, especially tapeworms, were among the major problems in poultry, both small-scale and commercial, which have caused enormous economic losses for chickens in the form of regrowth, weight loss, decreased egg production, diarrhea, and intestinal disorders, morbidity, and mortality (Hembram et al. 2015; Jatoi et al. 2018; Singh et al. 2021). Nematodes were the most significant helminths regarding species and distribution and caused many severe diseases in humans and animals. In addition, they had a significant economic impact on many agricultural products worldwide (Bazh 2013).

The Jember district of East Java province study showed that helminths infection prevalence in laying chickens is mostly caused by Ascaridia galli $(60 \%)$ (Kusuma et al. 2021). However, Molla et al. (2012) in Ethiopia reported that the prevalence of helminths infections in free-range chickens reached $79.62 \%$, and Abdullah and Mohammed (2013) study at Sulaimani Region, Iraq, found that the common endo-parasite was Heterakis gallinarum $81 \%$. Various helminths species were commonly found in indigenous chickens raised in backyards in Northern Thailand, i.e., $H$. gallinarum, $A$ galli, and Capillaria spp. (Wuthijaree et al. 2019). Berhe et al. (2019) study showed that the two most common helminths species found in chicken were $H$. gallinarum $(72.50 \%)$ and $A$. galli $(68.80 \%)$. Meanwhile, in three rural areas of Bangladesh, the Cestoda Raillietina spp. was the most common species (86-92\%), followed by A. galli (70-86\%) and $H$. gallinarum (70-76\%) (Ferdushy et al. 2016).

Rural communities are still considered to raise native chickens more than commercial chickens because they are more resistant to disease, including local parasite infections (Sumantri et al. 2020). Thus, the objective of this study was to determine the prevalence of parasitic helminths species in four strains of local Indonesian chickens, viz. Ranupane, Lokal Putih, Wareng, and Lurik and the impact on Hen Day Production (HDP).

\section{MATERIALS AND METHODS}

The origin of Ranupane strain was taken from the Ranupane Village of Senduro Sub-district at Lumajang
District. Then, Wareng from Malang District and Lurik from Jombang and Lamongan District. While Lokal Putih from Jombang District. All of the originated areas are located in East Java province, Indonesia (Figure 1), and the appearance of the chicken strain is shown in Figure 2. The observation of GIP infections in chickens was started at the age of six months. Furthermore, the daily egg production for hen days (HDP) was created from 7 to 12 months. The number of chickens in each strain was 70 (280 birds in total) (Table 1). After the chicken samples were taken from the different areas/geographical, they were kept on the Experimental Farm, University of Muhammadiyah Malang, East Java, Indonesia. The chicken was raised on a semiintensive model with a communal cage. Both male and female chickens were observed for helminths infections. The chickens were given standard feed, namely complete feed with $16 \%$ of based protein content.
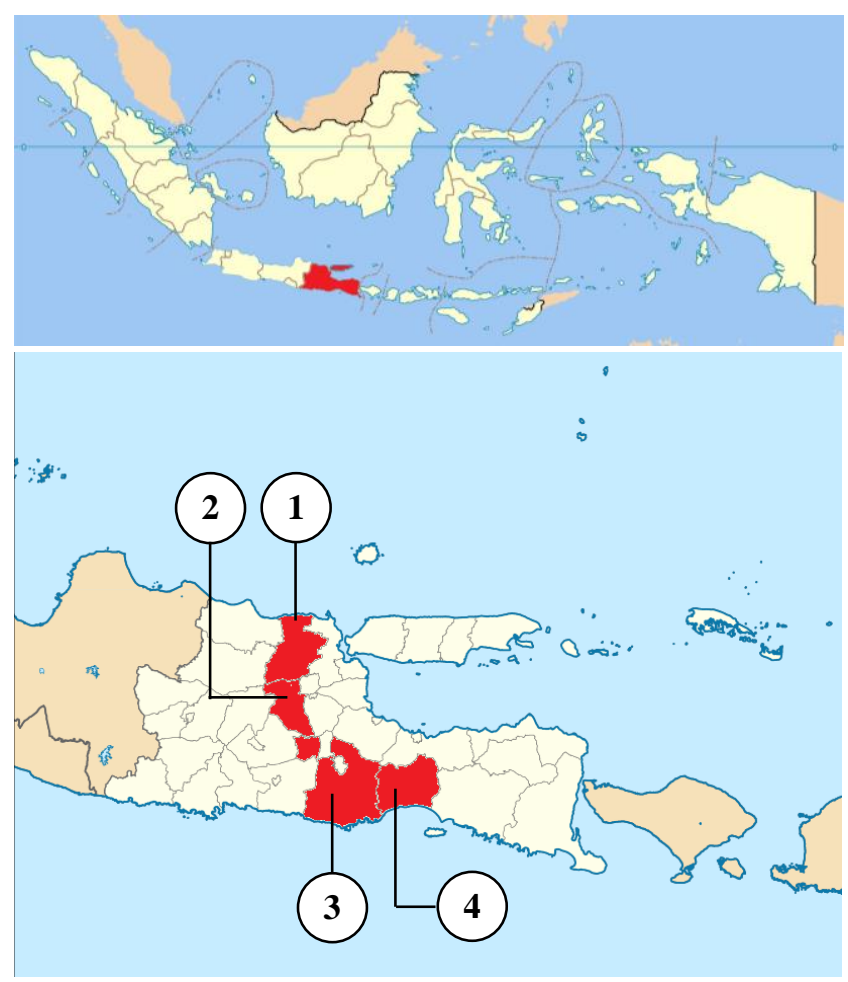

Figure 1. Geographical area of chickens sampling in East Java Province, Indonesia (gray shading), and the district area of chicken origin: 1. Lamongan, 2. Jombang, 3. Malang, and 4. Lumajang

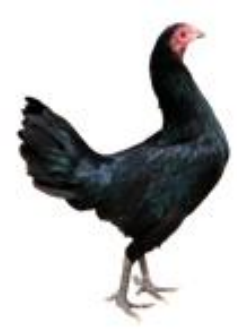

A

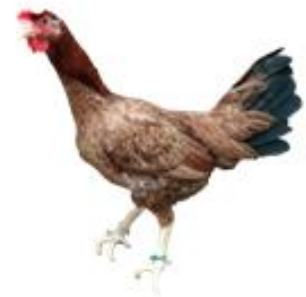

B

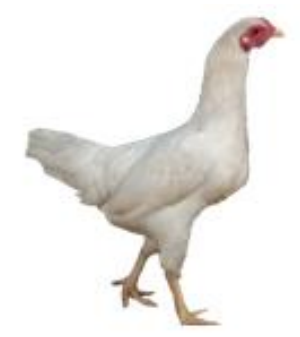

C

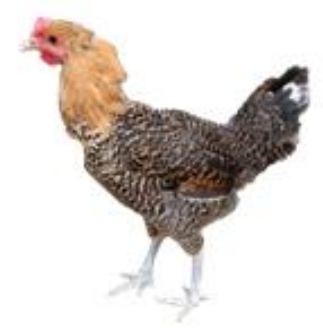

D

Figure 2. The chicken strain used in this study, A. Wareng, B. Ranupane, C. Lokal Putih, and D. Lurik 
Table 1. Strain, number, and sex of chickens used in the study

\begin{tabular}{lccc}
\hline Strain of chicken & $\begin{array}{c}\text { Number } \\
\text { (head) }\end{array}$ & $\begin{array}{c}\text { Female } \\
\text { (head /\%) }\end{array}$ & $\begin{array}{c}\text { Male } \\
\text { (head /\%) }\end{array}$ \\
\hline Ranupane & 70 & $55 / 78.57$ & $15 / 21.43$ \\
Lokal Putih & 70 & $51 / 72.86$ & $19 / 27.14$ \\
Wareng & 70 & $52 / 74.29$ & $18 / 25.71$ \\
Lurik & 70 & $53 / 75.71$ & $17 / 24.29$ \\
Total & 280 & $211 / 75.36$ & $69 / 24.64$ \\
\hline
\end{tabular}

\section{The investigation of gastrointestinal helminths}

The sensitivity and tolerance of chickens to helminths infections could be identified from the high and low percentage of positively infected chickens by helminths compared to the number of samples observed. Furthermore, the infection intensity was calculated from the number of helminths eggs found in chicken feces. Chicken feces samples were taken directly from the cloaca of each chicken sample, put in a plastic bag, and given $4 \%$ formalin to prevent the eggs hatched to be helminths larvae. All samples were stored in a cooled room for observation.

The investigation of helminths eggs was based on the McMaster method with slight modification (Chandrawathani et al. 2015; Riccio 2019; Wilkes et al. 2019) with a sensitivity of 100 helminths eggs per gram of feces. The used counting chamber with two compartments has a $10 \times 10 \mathrm{~mm}$ surface, and the space between an object-glass and a coverslip was $1.5 \mathrm{~mm}$. Thus, each compartment has a volume of $0.15 \mathrm{~mL}$ of liquid. Two grams of feces were dissolved in $60 \mathrm{~mL}$ of salt-saturated solution; hence, one gram of feces was in $30 \mathrm{~mL}$. Since one compartment of object-glass was $0.15 \mathrm{~mL}$ of volume, thus the number of eggs in one gram of feces was calculated by multiplying the number of eggs found $(\boldsymbol{y})$ by or 200. Then, the number Egg Per Gram (EPG) counted as follow:

$$
\mathrm{EPG}=\mathrm{y} \text { X } 200
$$

Where $\boldsymbol{y}$ is the number of eggs in one counting cell.

The study achieved at the Microbiology Laboratory, Department of Animal Science, Faculty of Agriculture and Animal Science, Universitas Muhammadiyah Malang.

\section{Hen Day Production (HDP)}

The daily egg production of chicken was calculated from the number of eggs produced by hen every day for each strain, and the HDP value (\%) was calculated according to the method described by Sharma et al. (2020);

Total number ofeggs produced on daily bas is HDP: Total number of chicken in flack on that day $X 100 \%$

The chickens were reared under semi-intensive conditions, and the colony consisted of five to ten hens. Each colony was set with one male for breeding ratio. The feeds for chickens were giving for average growth and production daily.

\section{Data analysis}

The data of eggs helminths and hen day production (HDP) were analyzed based on descriptive analysis. Descriptive analysis is a statistical method that is used to search and summarize historical data related to identifying patterns or meaning. Data aggregation and mining are two techniques to discover historical data in descriptive analysis. First, we applied the observational method to get the data, both quantitative and qualitative. Then the collected data was analyzed to determine the mean, maximum, minimum, and deviation value - also, data trend and highlight comparison (Ali and Bhaskar 2016). MS Excel and SPSS assisted the performed data analysis.

\section{RESULTS AND DISCUSSION}

\section{Helminths infection in native chicken}

Indonesian native chickens or Ayam Kampung are generally raised in free-range or backyard, thus allowing the chicken to exercise in the backyard during the day and stay in a chicken coop at night. This situation increases the possibility of chickens consuming various smaller animals such as grasshoppers, cockroaches, snails, flies, and ants, which can be an intermediate host of worms. Also, it allows chickens to consume foods contaminated by helminths eggs or larvae in the field accidentally. In this study, chicken samples were raised in a semi-intensive system with the ground floor, allowing the chicken to contact the land still.

Based on the study finding from 280 fecal samples, the percentage of chickens positively infected by parasitic helminths was $56.43 \%$ (Table 2). The percentage of parasitic helminths infections was higher than $38 \%$ reported in Ayam Kampung in Bangkalan, Madura, East Java province by Damayanti et al. (2019), also higher than what reported by Hariani and Simanjuntak (2021) in Muara Badak, Kutai Kertanegara of East Kalimantan 53.33\%. The differences in prevalence rates might be caused by several factors, including strain or breed, growth period of livestock, and environmental conditions. Differences in temperature and humidity can also affect helminths eggs/larvae growth and development in farm areas (Tarbiat et al. 2015).

The prevalence rates of GIP helminths in Ranupane, Wareng, and Lurik chickens were almost similar, around $51-52 \%$ (Table 2). At the same time, the prevalence of parasitic helminths in Lokal Putih chicken was higher $(68.57 \%)$ than in other chickens. This result might be due to the breed or strain genetic factors since the chicken samples were raised in similar conditions. The strain Lokal Putih is the offspring from Kedu chicken (particularly white Kedu), a local strain developed in the Central Java region more than centuries ago; thus, this chicken type was very adaptive to local environment and diseases (Ismoyowati et al. 2012; Ulfah et al. 2016; Nurcahya et al. 2020). Some chicken breeds or strains can deal with infectious diseases influenced by genetic factors (Maizels et al. 2012). 
The degree of helminths infection in the chicken's gastrointestinal tract was determined from the number of helminths eggs per gram of feces. Table 2 results showed that the degree of helminths infection reached 115 worm eggs per gram of feces. This value indicates that the degree of helminths infection is moderate since it is less than 500 eggs per gram of fecal. The degree of disease increased due to worms continued to reproduce and released worm eggs continuously. Thus, Lokal Putih chicken was with the highest percentage of helminths infection could be categorized into a moderate disease. The reported of helminths eggs where belong to Ascaridia galli, Heterakis gallinarium, Raillietina sp., and Capillaria sp. shows in Figure 3. The percentage rate of $A$. galli infection ranged from $51-76 \% ; H . \quad$ gallinarium 21-28\%; Railietina spp. 724\%; and Capillaria spp. (22\%). The most prevalent worm infecting chickens in this study was A. galli (Figure 4). The parasitic helminths can adapt to various fowl or aves species. Among the phylum Nematoda, the suborder Ascaridina is the important parasitic helminth in domestic animals, and human included superfamilies Ascaridoidea and Heterakoidea. The superfamilies have viz. Ascaris suum (pigs), Ascaris lumbricoides (humans), $\quad$ and $A$. galli and $H$. gallinarum (domestic poultry) (Tarbiat et al. 2015).

While Sherwin et al. (2013) reported that the helminths species with the highest infection rates in 16 flocks of freeranged housed commercial chicken farms across England and Wales was Heterakis sp. (89\%), furthermore, Van et al. (2020) study showed that the most prevalence helminths in the commercial small-scale chicken flock in the Mekong Delta of Vietnam were $H$. gallinarum $(43.3 \%$ and $42.2 \%$ in normal and sick chicken, respectively) then followed by $A$. galli $(26.7 \%$ and $41.1 \%)$. The study of Carrisosa et al. (2021) on non-commercial chicken or backyard in the Alabama state of US showed that the higher prevalence rate helminths eggs belonged to Capillaria spp. (26\%) and followed by A. galli and $H$. gallinarum (20\%, respectively). While at the free-range farm in Lower Saxony, Germany, the most prevalent species were $H$. gallinarum $(98.5 \%)$, followed by A. galli $(96.2 \%)$ and Capillaria spp. (86.1\%) (Wongrak et al. 2014). This variation was indicated that the management was influential in the free-range farming system (Gimba et al. 2019). However, in Southeastern Nigeria, the most prevalent GIP was cestodes (70.4\%) dominated by Raillietina spp. (Idika et al. 2016).

The egg of $A$. galli had higher resistance against environmental influences. Therefore, $a$. galli eggs could live and survive throughout the year in Sweden (Tarbiat et al. 2015). There was a direct relationship between temperature and the survival rate of $A$. galli eggs. This situation was increased proportionally by temperature increase up to $30{ }^{\circ} \mathrm{C}$ (Tarbiat et al. 2015). Temperature and humidity are often essential clues for the hatchability of helminths eggs that live freely in their environment. Changes in seasonal temperature have different impacts on the development and hatching rate of two gastrointestinal nematodes in the foliage (Hernandez et al. 2013). In the East Java region, air temperature ranged from $27.53{ }^{\circ} \mathrm{C}$ to $29.80^{\circ} \mathrm{C}$ (BPS Jatim 2020). Thus, the temperature is suitable for developing $A$. galli eggs and becomes the reason for the familiar presence of $A$. galli infections in tropical regions, including Indonesia. However, interestingly, Lambert et al. (2015) reported that the third stage infected larvae (L3) and adult helminth and the adult secretory/excretory product were in line with IgG level and part IgA antibody. Additionally, the egg yolk of the IgY antibody had a strong reaction with antigen on the part of tissues infected by A. galli (Darmawi et al. 2012). Hence, the genetics factor can be considered to protect the chicken from GIP helminths.

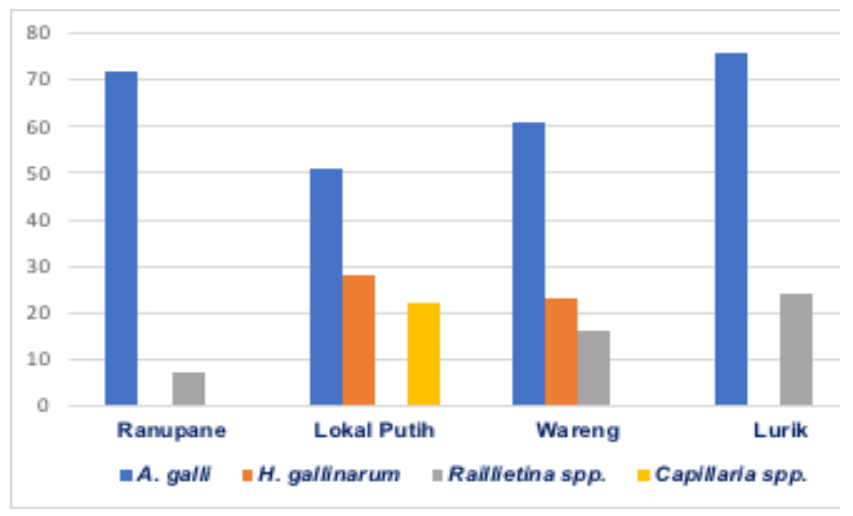

Figure 3. Prevalence of GIP helminths infected native chicken strain $(\%)$

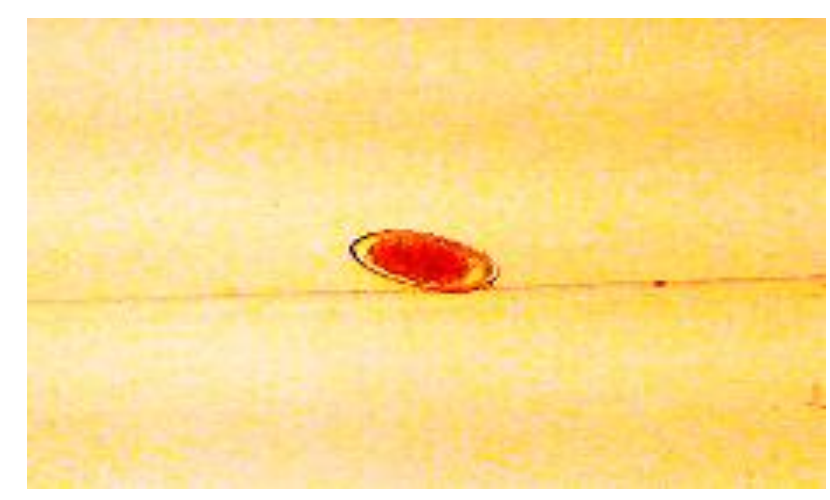

Figure 4. Ascaridia galli egg

Table 2. Infection rates and numbers of eggs gastrointestinal helminths parasites in native chicken strain

\begin{tabular}{lccc}
\hline $\begin{array}{c}\text { Chicken } \\
\text { strain }\end{array}$ & $\begin{array}{c}\text { Number of } \\
\text { chicken }\end{array}$ & $\begin{array}{c}\text { Infection } \\
\text { degrees } \\
(\%)\end{array}$ & $\begin{array}{c}\text { Number of } \\
\text { helminth egg (per } \\
\text { g feces) }\end{array}$ \\
\hline Ranupane & 70 & 52.86 & 142 \\
Lokal Putih & 70 & 68.57 & 134 \\
Wareng & 70 & 51.45 & 75 \\
Lurik & 70 & 52.86 & 109 \\
Average & & $56.43 \pm 8.12$ & $115 \pm 30.14$ \\
\hline
\end{tabular}


Table 3. Hen Day Production (HDP) (\%) of native chicken

\begin{tabular}{lcccc}
\hline $\begin{array}{l}\text { Age } \\
\text { (months) }\end{array}$ & Lurik & Wareng & $\begin{array}{l}\text { Lokal } \\
\text { Putih }\end{array}$ & Ranupane \\
\hline 7 & 49.13 & 50.87 & 52.81 & 55.82 \\
8 & 40.72 & 35.94 & 50.56 & 39.59 \\
9 & 39.48 & 45.07 & 35.75 & 34.37 \\
10 & 44.30 & 32.93 & 44,22 & 32.45 \\
11 & 48.80 & 22.40 & 12.80 & 30.90 \\
12 & 52.40 & 19.50 & 22.20 & 22.10 \\
Average & $45.80 \pm 5.13$ & $34.36 \pm 12.29$ & $36.39 \pm 16.06$ & $35.87 \pm 11.31$ \\
\hline
\end{tabular}

\section{Hen day production (HDP) of local chicken}

The average HDP of Lurik, Wareng, Lokal Putih, and Ranupane chickens at the age of 7 to12 months (along six months of chicken raised) was $45.80 \%$; $34.36 \%$; $36.39 \%$, and $35.87 \%$, respectively (Table 3 ). This value was lower than Sartika et al. (2011) study based on the $M x$ gene of native chicken (60-64\%) and Yaman et al. (2020) on crossbred Indonesian native chicken by average $47.80 \%$. However, it was higher than Aseel chicken of Indian native chicken $(36.23 \%)$ at 70 weeks (Haunshi et al. 2011). In the current study, Lurik chicken had the highest HDP value by an average of $45.80 \%$ from 7 to 12 months of age. It has been known that Lurik chicken is a hybrid strain of Arab chicken where the ancestor presumably came from an introduced breed, namely Kriel Braekels from Belgium. Arab chicken is the only laying type in Belgium. This chicken was categorized as one of the native chickens adaptable to the climate in Indonesia (Gunawan et al. 2018) and quite potential as a layer due to high egg productivity close to the domestic layer.

According to the finding of Dastagir et al. (2017), the free-range chicken was more resistant to parasite infestations, both ectoparasites, and endoparasites than those of the intensive and closed house rearing system. Free-range chickens freely exchange air and light due to their environmental situation; hence they have stronger immunity. Therefore, in intensive rearing, it is suggested that the cage must enable chickens to exchange air and light freely. Also, immunization should be done regularly both on ectoparasites and endoparasites. In addition, the result data in Table 3 showed although the degree of infection was moderate, all four chicken strains were able to tolerance against parasitic helminths infection; thus, the chicken productivity was not affected. The environmental conditions also affected egg productivity, like wind speed (1.46 m/s), lighting (17.53 lux), humidity (72.11\%), and temperature $\left(27.71^{\circ} \mathrm{C}\right)$, cumulatively giving a $31.4 \%$ effect on the productivity of the KUB native chicken (Damayanti et al. 2019).

The gastrointestinal parasites such as Eimeria spp., A. galli, $H$. gallinarum, and Capillaria spp. were responsible for the most frequent and economic losses in poultry farming (Lozano et al. 2019). The impact of nematode infection in chickens includes health problems, production performance due to reduced feed conversion ratio, decreased growth rate or weight loss, decreased egg production and egg quality, intestinal damage, and in severe cases, death (Javaregowda et al. 2016; Sreedevi et al. 2016; Rufai and Jato 2017; Wokem and Obiyor 2018). Raillietina species were frequently found in domestic chickens (Gallus gallus domesticus) in Phayao province, Northern Thailand. Raillietina infections potentially induced illness and death (Butbonchoo et al. 2016). At the same time, $H$. gallinarum helminths play an essential role in transmitting histomoniasis disease (blackhead disease) (Goater et al. 2014). Histomoniasis causes necrosis of the liver and caecum tissue, then the cecum and liver will become inflamed and develop ulcers (Dolka et al. 2015; USFDA 2019).

Based on the study findings, biosecurity implementation requires more attention. It is expected to overcome helminths infections, especially in native chickens, both at free range and intensively rearing management. Native chicken managed with backyard and semi-intensive systems have two to four times infection risk caused by helminth parasites (Berhe et al. 2019). Besides that, the use of anthelmintics in Indonesia generally has been limited due to the resistance effect and prohibited in organic production systems; thus, the management of backyard and free-range rearing of native chicken needs special attention regarding gastrointestinal infection. In Asia and Africa, including Indonesia, native chicken is predominant; consequently, it is susceptible to helminths infections. Additionally, native chicken is still favorable to most people because it has more value than domestic chicken, especially on taste and flavor, also has a higher selling price.

In conclusion, the prevalence of helminthiasis in four strains of Indonesian native chickens reached $56.43 \%$, and the degree of infection was categorized in moderate level by $115 \mathrm{EPG}$ of feces. The HDP of four chicken strains at the age of 7 to 12 months was normal, ranging from 43$48 \%$. The parasitic helminth species found during the study were $A$. galli, $H$. gallinarum, Raillietina spp., and Capillaria spp. At the same time, A. galli was the most commonly reported species found. All four strains of native chicken were tolerant against helminths infections by demonstrating that the HDP value was still in the normal range.

\section{ACKNOWLEDGEMENTS}

The authors gratefully thank the Rector University of Muhammadiyah Malang, Indonesia, for the support and permission of the research were conducted successfully. This research is part of the National Research Project funded by the Ministry of Research and Technology / National Research Agency, the Republic of Indonesia in 2020 by contract number: 7/EI/II/PRN/2020.

\section{REFERENCES}

Abdullah S, Mohammed A. 2013. Ecto and endo parasites prevalence in domestic chickens in Sulaimani Region. The Iraqi J Vet Med 37(2): 149-155. DOI: 10.30539/iraqijvm.v37i2.275. 
Ali Z, Bhaskar SB. 2016. Basic statistical tools in research and data analysis. Indian J Anaesth 60(9): 662-669. DOI: 10.4103/00195049.190623.

Asmelash B, Dawit M, Kebede E. 2018. Characterization of village chicken production and breeding practices of smallholders in Eastern Ethiopia. J Vet Sci Technol 9: 507. DOI: 10.4172/21577579.1000507.

Azzez OI, Oyagbemi AA, Iji OT. 2012. Haematology and erythrocyte osmotic fragility indices in domestic chicken following exposure to a polyvalent iodophorous disinfectant. Jordan J Biol Sci 5(2): 99-103.

Bachaya HA, Raza MA, Anjum MA, Khan IA, Aziz A, Manzoor Z, Munawar SH. 2015. Prevalence of Ascaridia galli in white leghorn layer and Fayoumi-Rhode Island red crossbred flock at government poultry farm Dina, Punjab, Pakistan. Trop Biomed 32(1): 11-16.

Bazh EKA. 2013. Molecular characterization of Ascaridia galli infecting native chickens in Egypt. Parasitol Res 112: 3223-3227. DOI: 10.1007/s00436-013-3498-9.

Berhe M, Mekibib B, Bsrat A, Atsbaha G. 2019. Gastrointestinal helminth parasites of chicken under different management system in Mekelle Town, Tigray Region, Ethiopia. J Vet Med 2019: 1-7. DOI 10.1155/2019/1307582.

BPS [Badan Pusat Statistik] [Central Statistics Bureau]. 2021. Population of native chicken based on province, 2018-2020. Available at: https://www.bps.go.id/indicator/24/476/1/populasi-ayam-burasmenurut-provinsi-.html. Accessed on Februari 2021

BPS Jatim [Badan Pusat Statistik Provinsi Jatim] [Central Statistics Bureau of East Java Province]. 2020. The Degree of temperature and humidity in East Java. [Indonesian]. Available at: https://jatim.bps.go.id. Accessed on Oct. 2020.

Butbonchoo P, Wongsawad C, Rojanapaibul A, Chai J. 2016. Morphology and molecular phylogeny of Raillietina spp. (Cestoda: Cyclophyllidea: Davaineidae) from domestic chickens in Thailand. Korean J Parasitol 54(6): 777-786. DOI: 10.3347/kjp.2016.54.6.777.

Carrisosa M, Jin S, McCrea BA, Macklin KS, Dormitorio T, Hauck R. 2021. Prevalence of select intestinal parasites in Alabama backyard poultry flocks. Animals 11(4): 939. DOI: 10.3390/ani11040939.

Chandrawathani P, Premaalatha B, Jamnah O, Priscilla FX, Erwanas AI, Lili RMH, Jackie P, Josephin SJAL. 2015. McMaster method of worm egg count from faecal samples of goats: A comparison of single and double chamber enumeration of worm eggs. Malay J Vet Res 6(1): 81-87.

Damayanti EA, Hastutiek P, Estoepangestie ATS, Retno NDL, Kusnoto, Suprihati E. 2019. The prevalence and infection's degree of gastrointestinal worm of local chicken (Gallus Domesticus) in Kramat Village, District of Bangkalan, Madura, East Java Indonesia. J Parasite Sci 3(1): 41-46. DOI: 10.20473/jops.v3i1.16436.

Darmawi, Balqis, Hambala M, Tiuria R, Priosoeryanto BP, Handharyani E. 2012. The ability of immunoglobulin yolk recognized the antigen in the tissue of Ascaridia galli. Media Peternakan 35(3): 190-195. DOI: 10.5398/medpet.2012.35.3.190. [Indonesian]

Dastagir M, Yasmeen M, Kannarath A. 2017. A comparative study of ecto and endo parasites of free range and captive Fowl in Sangli District Maharashtra. GSC Bio Pharm Sci 1(3): 54-58. DOI: 10.30574/gscbps.2017.1.3.0056.

Di Pillo F, Anríquez G, Pablo A, Pedro JB, Pablo G, Vanesa N, Stacey SC, Christopher HW. 2019. Backyard poultry production in Chile: Animal health management and contribution to food access in an upper middle-income country. Prevent Vet Med 164: 41-48. DOI: 10.1016/j.prevetmed.2019.01.008.

Dolka B, Żbikowski A, Dolka I, Szeleszczuk. 2015. Histomonosis- an existing problem in chicken floks in Poland. Vet Res Commun 39: 189-195. DOI: 10.1007/s11259-015-9637-2.

Ferdushy T, Hasan MT, Golam KAKM. 2016. Cross sectional epidemiological investigation on the prevalence of gastrointestinal helminths in free range chickens in Narsingdi district, Bangladesh. J Parasitol Dis 40: 818-822. DOI: 10.1007/s12639-014-0585-5.

Gimba FI, Ola-Fadunsin SD, Abdullah DA, Konto M, Daudu BB, Abubakar D. 2019. Prevalence of ecto and endo parasites of chickens in some villages in Taraba state, North-Eastern Nigeria. Livest Res Rural Dev 31: 50.

Goater TM, Goater CP, Esch GW. 2014. Nematoda: The roundworms. In: Goater TM, Goater CP, Esch GW (eds). Parasitism - The Diversity and Ecology of Animal Parasites. $2^{\text {nd }}$ Edition. Cambridge University Press, UK. DOI: 10.1017/CBO9781139047876.

Gunawan E, Kaharuddin D, Kususiyah. 2018. Performance of Arras chicken descendants with Arabic chickens (Ketarras chickens) aged
2-12 Weeks. Indo J Anim Sci 13(1): 89-100. DOI: 10.31186/jspi.id.13.1.89-100.

Hariani H, Simanjuntak I. 2021. Prevalence and intensity of parasite worm eggs in Kampung Chickens and Laying Chickens in Muara Badak District, Kutai Kartanegara. J Ilmu Dasar 22(1): 1-8. DOI: 10.19184/jid.v22i1.11092. [Indonesian]

Haunshi S, Niranjan M, Shanmugam M, Padhi MK, Reddy MR, Sunitha R, Rajkumar U, Panda AK. 2011. Characterization of two Indian native chicken breeds for production, egg and cement quality, and welfare traits. Poul Sci 90(2): 314-320. DOI: 10.3382/ps.2010-01013.

Hembram A, Panda MR, Mohanty BN, Pradhan CR, Dehuri M, Sahu A, Behera M. 2015. Prevalence of gastrointestinal helminths in Banaraja fowls reared in semi-intensive system of management in Mayurbhanj district of Odisha. Vet World 8(6): 723-726. DOI: 10.14202/vetworld.2015.723-726.

Hernandez AD, Poole A, Cattadori IM. 2013. Climate changes influence free-living stages of soil-transmitted parasites of European rabbits. Glob Change Biol 19(4): 1028-1042. DOI: 10.1111/gcb.12106.

Idika IK, Obi CF, Ezeh IO, Iheagwam CN, Njoku IN, Nwosu CO. 2016. Gastrointestinal helminth parasites of local chickens from selectedcommunities in Nsukka region of south eastern Nigeria. J Parasite Dis 40(4): 1376-1380. DOI: 10.1007 / s12639-015-0694-9.

Ismoyowati, Sukardi, Susanto A. 2012. Genetic diversity of Kedu Chicken based on phenotypic characteristics and microsatellite loci. Int J Poult Sci 11: 605-610. DOI: 10.3923/ijps.2012.605.610.

Jatoi AS, Akhter N, Bughio E, Mirani AH, Bhutto B. 2018. Prevalence of cestodes in selected small scale commercial poultry farms of Hyderabad Sindh. Sir J Agri Agril Engg Vet Sci 34(1): 87-93.

Javaregowda AK, Kavitha Rani B, Revanna SP, Udupa G. 2016. Prevalence of gastro-intestinal parasites of backyard chickens (Gallus domesticus) in and around Shimoga. J Parasit Dis 40: 986-990. DOI: 10.1007/s12639-014-0620-6.

Krauß M, Keßler J, Prochnow A, Kraatz S, Drastig K. 2015. Water productivity of poultry production: The influence of different broiler fattening systems. Food Energy Secur 4(1): 76-85. DOI: 10.1002/fes3.51.

Kumar M, Dahiya SP, Ratwan P. 2019. Backyard poultry farming in India: A tool for nutritional security and women empowerment. Biol Rhythm Res 1-16. DOI: 10.1080/09291016.2019.1628396.

Kusuma SB, Nusantoro S, Muhamad N, Awaludin A, Hasanah N, Adhyatma M. 2021. Identification of helminth parasites diversity on laying chicken in Jember district (East Java- Indonesia). IOP Conf Ser Earth Environ Sci 672(1): 012045. DOI: 10.1088/17551315/672/1/012045

Lambert KA, Pathak AK, Cattadori IM. 2015. Does host immunity influence helminth egg hatchability in the environment? J Helminth 89(4): 446-452. DOI: 10.1017/S0022149X14000273.

Lozano J, Anaya A, Salinero AP, Hoppe EGL, Gomes L, Paz-Silva A, Rebelo MT, Madeira DL. 2019. Gastrointestinal parasites of freerange chickens-A worldwide issue. Bull Univ Agric Sci Vet Med Cluj-Napoca Vet Med 76(2): 110-117. DOI: 10.15835/buasvmenvm:2019.0019.

Maizels RM, Hewitson JP, Smith KA. 2012. Susceptibility and immunity to helminth parasites. Curr Opinion Immun 24: 459-466. DOI: 10.1016/j.coi.2012.06.003.

Mengesha M. 2012. Indigenous chicken production and the innate characteristics. Asian J Poul Sci 6: 56-64. DOI:
. 10.3923/ajpsaj.2012.56.64.

Molla W, Haile H, Almaw G, Temesgen W. 2012. Gastrointestinal helminths of local backyard chickens in North Gondar Administrative Zone, Ethiopia. Rev de Med Vet 163(7): 362-367.

Negbenebor HE, Ali M. 2018. Prevalence of gastro-intestinal parasites of local chickens (Gallus gallus domestica) in Kano, Nigeria. Ann Microb Infec Dis 1(4): 45-49.

Nurcahya H, Sinaga E, Darwati S, Khaerunissa I. 2020. Relationship between of Insuline Like growth Factor-2 gene and growth traits in crosses of Indonesian local chicken. J Phys Conf Ser 1665(2020): 1-5. DOI: 10.1088/1742-6596/1665/1/012015.

OECD/Food and Agriculture Organization of the United Nations. 2013. OECD-FAO Agricultural Outlook 2013. OECD Publishing. DOI: 10.1787/agr_outlook-2013-en.

Riccio C. 2019. Counting Worms/C. elegans /Nematodes. protocols.io. DOI: 10.17504/protocols.io.5ung6ve.

Rufai MA, Jato AO. 2017. Assessing the prevalence of gastrointestinal tract parasites of poultry and their environmental risk factors in 
poultry in Iwo, Osun State Nigeria. Ife J Sci 19(1): 7-13. DOI 10.4314/ijs.v19i1.2.

Sartika T, Sulandari S, Zein MSA. 2011. Selection of Mx gene genotype as genetic marker for Avian Influenza resistance in Indonesian native chicken. BMC Proc 5: S37. DOI: 10.1186/1753-6561-5-S4-S37.

Sharma MK, Dinh T, Adhikari PA. 2020. Production performance, egg quality, and small intestine histomorphology of the laying hen supplemented with phytogenic feed additive. J Appl Poult Res 29(2): 362-371. DOI: $10.1016 /$ j.japr.2019.12.001.

Sherwin CM, Nasr MAF, Gale E, Petek M, Stafford K, Turp M, Coles GC. 2013. Prevalence of fecal and nematode infection in laying hens clearances: Relationship to house and farms. British Poult Sci 54(1): 12-23. DOI: $10.1080 / 00071668.2012 .757577$

Singh M, Kaur P, Singla LD, Kashyap N, Bal MS. 2021. Assessment of risk factors associated with prevalence of gastrointestinal parasites in poultry of central plain zone of Punjab, India. Vet World 14(4): 972977. DOI: $10.14202 /$ vetworld.2021.972-977.

Siracusa MC, Gause WC. 2016. Immunity to Parasitic Worms. In: eLS. John Wiley \& Sons, Ltd, Chichester. DOI: 10.1002/9780470015902.a0000482.pub2.

Sreedevi C, Jyothisree Ch, Rama Devi V, Annapurna P, Jeyabal L. 2016. Seasonal prevalence of gastrointestinal parasites in desi fowl (Gallu. gallus domesticus) in and around Gannavaram, Andhra Pradesh. J Parasit Dis 40: 656-661. DOI: 10.1007/s12639-014-0553-0.

Sumantri C, Khaerunnisa I, Gunawan A. 2020. The genetic quality improvement of native and local chickens to increase production and meat quality in order to build the Indonesian chicken industry. IOP Conf Ser Earth Environ Sci 492: 012099. DOI:10.1088/17551315/492/1/012099.

Tarbiat B, Jansson DS, Hoglund J. 2015. Environmental tolerance of freeliving stages of the poultry roundworm Ascaridia galli. Vet Parasitol 209(1-2): 101-107. DOI: 10.1016/j.vetpar.2015.01.024.

Tarkhan AH, Saleh KMM, Al-Zghoul MB. 2020. Heat exposure affects then mRNA levels of antioxidant enzymes in embryonic and adult broiler chickens. Jordan J Biol Sci 13(4): 431-435.
Ulfah M, Kawahara-Miki R, Farajalllah A, Muladno M, Dorshorst B, Martin A, Kono T. 2016. Genetic features of red and green junglefowls and relationship with Indonesian native chickens Sumatera and Kedu Hitam. BMC Genom 17: 320. DOI: $10.1186 / \mathrm{s} 12864-016-2652-\mathrm{z}$.

USFDA [United Stated Food and Drug Administration]. 2019. Blackhed disease in poultry. www.fda.gov/animal-veterinary/resourcesyou/blackhead-disease-poultry. Accessed on January 2021

Van NTB, Cuong NV, Yen NTP, Nhi NTH, Kiet BT, Hoang NV, Hien VB, Thwaites G, Carrique-Mas JJ, Ribas A. 2020. Characterization of gastrointestinal helminths and their impact in commercial small-scale chicken flocks in the Mekong Delta of Vietnam. Trop Anim Health Prod 52: 53-62. DOI: 10.1007/s11250-019-01982-3.

Wilkes EJA, Woodgate RG, Raidal SL, Hughes KJ. 2019. The application of faecal egg count results and statistical inference for clinical decision making in foals. Vet Parasitol 270: 7-12. DOI: 10.1016/j.vetpar.2019.04.010.

Wokem G, Obiyor E. 2018. Assessment of intestinal parasites of commercial layers in selected local government areas of Rivers State, Nigeria and their public health implications. Curr Trends Biomed Eng Biosci 11(5): 555822. DOI: 10.19080/CTBEB.2018.11.555822.

Wongrak K, Daş G, Moors E, Sohnrey B, Gauly M. 2014. Establishment of gastro-intestinal helminth infections in free-range chickens: A longitudinal on farm study. Berl Munch Tierarztl Wochensch 127(78): 314-321. DOI: $10.2376 / 0005-9366-127-314$

Wuthijaree K, Lambertz C, Vearasilp T, Anusatsananun V, Gauly M. 2019. Prevalence of gastrointestinal helminths in Thai indigenous chickens raised under backyard conditions in Northern Thailand. J App Poul Res 28(1): 221-229. DOI: 10.3382/japr/pfy062.

Yaman MA, Erina, Zulfan, Yusman, C A Fitri CA, Latif H. 2020. Increase in egg production, egg quality and immunity of local chicken by cross-breeding. IOP Conf Ser Earth Environ Sci 425: 012043. DOI: $10.1088 / 1755-1315 / 425 / 1 / 012043$. 